\title{
Pemberdayaan Masyarakat Pengrajin Gitar di Desa Mancasan, Baki, Kabupaten Sukoharjo Menuju Pasar Global
}

\author{
Sri Riris Sugiyarti; Unisri; Surakarta; email : ririss68@gmail.com \\ Hasna Wijayati; Unisri; Surakarta; email : hasna.fisip@gmail.com
}

\begin{abstract}
ABSTRAK
Industri gitar di Desa Mancasan, Baki, Kabupaten Sukoharjo adalah salah satu sektor ekonomi yang memiliki potensi besar. Mayoritas pelaku industri adalah Usaha Mikro, Kecil dan Menengah (UMKM). Namun, produksinya telah menembus pasar ekspor. Penelitian ini bertujuan untuk memperoleh gambaran tentang bagaimana memberdayakan komunitas pengrajin gitar di Desa Mancasan, Baki, Kabupaten Sukoharjo menuju pasar global. Penelitian ini adalah penelitian deskriptif kualitatif dengan objek penelitian adalah UMKM pengrajin gitar di Desa Mancasan, Baki, Sukoharjo. Sumber data primer dan sekunder dikumpulkan melalui teknik wawancara mendalam, observasi dan analisis dokumen. Data yang dikumpulkan kemudian dianalisis menggunakan model analisis interaktif untuk mendapatkan jawaban dari perumusan masalah. Hasil penelitian dipetakan ke dalam empat aspek, berupa : bina manusia, bina usaha, bina lingkungan, dan bina kelembagaan, dan dilengkapi dengan strategi ekspor. Dapat disimpulkan bahwa pemerintah memiliki peran dalam mengelola keempat aspek ini, walaupun belum maksimal. Peran terbesar pemerintah dalam pengembangan manusia terletak pada bimbingan teknis, sedangkan dalam aspek bina usaha dalam hal mendirikan badan usaha yang legal. Dalam strategi ekspor, hanya beberapa bisnis yang dapat menembus pasar ekspor. Sementara mayoritas UKM telah mencoba memperluas pasar ekspor tetapi masih dalam proses.
\end{abstract}

Kata kunci: Industri Gitar, Desa Mancasan, UMKM, Pemberdayaan

\section{ABSTRACT}

The guitar industry at Mancasan Village, Baki, Sukoharjo Regency is one of the economic sectors that has great potential. The majority of industry players are Micro, Small and Medium Enterprises (MSMEs). However, its production has penetrated the export market. This research aims to obtained on how to empower the community of guitar craftsmen in Mancasan Village, Baki, Sukoharjo Regency towards a global market. This research was a qualitative descriptive study by UMKM guitar craftsman as the object, located in Mancasan Village, Baki, Sukoharjo. Primary and secondary data sources were collected through in-depth interview techniques, observation and document analysis. The data collected was then analyzed using an interactive analysis model to get answers from the problem formulation. The results of the study were mapped into four aspects : human development, business development, environmental development, and institutional development, and complemented by an export strategy. It was known that the government had a role in managing these four aspects, although it was not yet maximized. The biggest role of government in human development lies in the technical guidance, while in the aspect of business development in terms of establishing legal business entities. In the export strategy, only a few businesses can penetrate the export market. While the majority of SMEs have tried to expand the export market but were still in the process.

Keyword: Development, Guitar Industry, Mancasan Village, SMEs. 


\section{Pendahuluan}

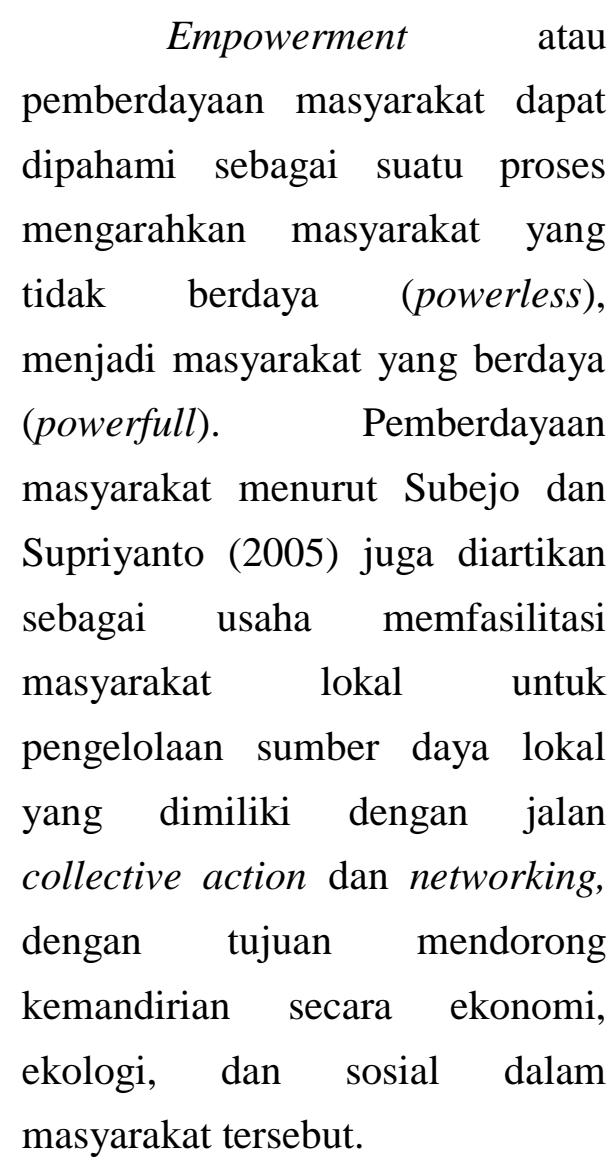

Secara sederhana, tujuan pemberdayaan masyarakat adalah membangun kemandirian masyarakat. Salah satu upaya untuk mewujudkan kemandirian masyarakat secara ekonomi dapat dilakukan denagn memberikan dukungan kegiatan ekonomi kewirausahaan, seperti bagi para pengusaha Usaha Mikro Kecil dan Menengah

(UMKM).

Pengembangan UMKM dapat dilakukan melalui program pemberdayaan masyarakat yang melibatkan berbagai stakeholders.

Setidaknya, Alsop, dkk (2006), menyebutkan ada 3 (tiga) aktor dominan yang dapat terlibat dalam program pemberdayaan, yang meliputi : aktor sipil/ negara (state), aktor ekonomi/ pasar (market), dan aktor sosial/ masyarakat (society). Merujuk pada adanya ketiga aktor tersebut, dapat pula diartikan bahwa pemberdayaan masyarakat merupakan manifestasi paradigma Good Governance. Paradigma Good Governance sendiri di dalamnya mencakup tiga pilar utama, berupa masyarakat, pemerintah, dan sektor private. Hal ini juga berarti bahwa melalui Good Governance sebagai penciptaan hubungan sinergis dan konstruktif di antara negara, sektor swasta dan masyarakat, dapat tercipta pemberdayaan masyarakat secara efektif (Sedarmayanti, 2012).

\section{Pemberdayaan}

masyarakat yang efektif dapat dilihat dari bagaimana pemerintah mengelola

UMKM-nya. Kabupaten Sukoharjo, sebagai lokasi penelitian, adalah sebuah kota dengan jumlah UMKM yang tinggi. Ada berbagai jenis UMKM yang berderak di wilayah ini. Namun, sektor yang paling banyak berkontribusi terhadap perkembangan ekonomi Kabupaten Sragen adalah sektor 
Industri. Setidaknya, sektor industri menyumbang distribusi PRDB Kabupaten Sukoharjo sebesar 39,60\% pada tahun 2016 (sukoharjo dalam angka 2016). Sektor industri di Kabupaten Sukoharjo masih terbagi dalam 3 cluster utama, berupa (1) industri hutan agro dan hasil hutan (IAHH), (2) industri tekstil dan aneka (ITA) serta (3) industri kimia, logam, mesin dan elektro (IKLME). Dari ketiga jenis cluster industri inilah, Kabupaten Sukoharjo mendapatkan produkproduk unggulan, yang salah satunya adalah produk gitar.

Industri gitar di Sukoharjo dianggap sebagai salah satu industri kecil yang memiliki potensi besar. Industri gitar ini menghasilkan produk kerajinan dengan nilai seni dan budaya yang sekaligus memiliki nilai jual tinggi. Salah satu sentra industri gitar ini berada di Desa Mancasan Kecamatan Baki, Sukoharjo. Produk gitar dari wilayah ini bahkan telah menembus pasar Global, hingga ke wilayah Malaysia, Denmark dan Jerman. Kebanyakan dari para pengrajin gitar tersebut masih tergolong UMKM.

Potensi industri gitar yang besar di wilayah ini juga menjadi potensi untuk meningkatkan perekonomian masyarakat sekitar. Ketika pemberdayaan masyarakat setempat dilakukan secara maksimal, potensi pengembangan ekonomi juga akan berjalan meningkat. Selama ini, Banyak bahan baku gitar yang diimpor dari luar negeri. Ini mengakibatkan harga produksi gitar cukup tinggi. Padahal, hasil produk gitar cukup rendah ketika dibeli oleh pengepul. Kondisi ini berdampak pada rendahnya tingkat kesejahteraan pengrajin gitar di wilayah tersebut.

Padahal, industri gitar memiliki potensi penyerapan tenaga kerja dan pemberdayaan masyarakat yang tinggi. Untuk itu, dibutuhkan dukungan dari pemerintah pusat dan pemerintah daerah untuk memajukan potensi lokal industri gitar di Desa Mancasan, sehingga potensinya menuju ke pasar global dapat lebih maksimal dan memberikan tingkat kesejahteraan yang maksimal pula bagi para pengrajinnya.

Dalam hal ini, dirasa penting untuk mengetahui bagaimana proses pemberdayaan masyarakat yang dilakukan terhadap para pengrajin gitar di Desa Mancasan, sehingga produknya dapat menembus pasar 
global secara maksimal. Produk yang menembus pasar global diharapkan tidak hanya mampu berkembang dalam segi kuantitas, melainkan dari kualitasnya. Tidak hanya itu, pemberdayaan masyarakat bagi para UMKM pengrajin gitar tersebut diharap dapat efektif terhadap usaha peningkatan kesejahteraan masyarakat pengarjinnya. Penelitian ini berusaha mengkaji bagaimana pemberdayaan masyarakat pengrajin gitar di Desa Mancasan, Baki, Kabupaten Sukoharjo menuju pasar global. Tujuan penelitian adalah untuk mendiskripsikan usaha-usaha pemerintah dalam melakukan pembinaan UMKM berbasis pemberdayaan masyarakat terhadap para pengrajin gitar di Desa Mancasan, Baki, Kabupaten Sukoharjo, dari segi pengembangan kapasitas Sumber Daya Manusia (SDM) serta pemaksimalan potensi ekspornya.

\section{Metode Penelitian}

Penelitian ini merupakan jenis penelitian deskriptif kualitatif. Travers (Sevilla, dkk, 1993), mengungkapkan bahwa metode deskriptif tepat digunakan dalam menggambarkan sifat keadaan yang berjalan pada saat penelitian dilakukan, dan untuk memeriksa sebab-sebab dari suatu gejala tertentu. Penelitian dengan deskriptif kualitatif tepat digunakan untuk memaparkan rumusan masalah penelitian yang berupa kajian terkait pembinaan UMKM berbasis pemberdayaan masyarakat di Kabupaten Sukoharjo, yang dilihat dari segi pengembangan kapasitas SDM dan usahanya menuju pasar global.

Penelitian dilakukan di Desa Mancasan, Kecamatan Baki, Kabupaten Sukoharjo, di sentra industri pengrajin gitar. Lokasi dipilih karena memiliki jumlah UMKM Binaan dalam jumlah cukup banyak di bidang pengrajin gitar. UMKM pengrajin gitar memiliki potensi untuk berkembang di pasar ekspor, mengingat beberapa pengrajin disana telah memulai ekspor produk gitarnya ke beberapa negara. Adapun objek penelitian meliputi individu-individu yang terlibat dalam pembinaan UMKM berbasis pemberdayaan masyarakat di Kabupaten Sukoharjo, dengan objek penelitian dikaji dari segi pengembangan kapasitas Sumber Daya Manusia (SDM) dan usahanya menuju pasar global.

Teknik penarikan sampel menggunakan metode purposive 
sampling. Menurut Sugiyono (2009), purposive sampling adalah teknik penentuan sampel yang dilakukan dengan pertimbangan tertentu, seperti kompetensi informan. Penggunaan metode purposive sampling dilakukan dengan memilih informan yang dinilai memiliki kompetensi cukup terkait pembinaan Usaha UMKM berbasis pemberdayaan masyarakat di kalangan pengrajin gitar Desa Mancasan. Adapun informan yang digunakan dalam penelitian ini terdiri dari Pengrajin Gitar Senior (Setiyadi); Sekretaris paguyuban (Sumardi); Ketua Paguyuban Pengrajin Gitar Amanah (Mulyanto); serta didukung dengan data yang diberikan dari Pemerintah Kabupaten Sukoharjo,

$$
\text { Data yang digunakan }
$$

berupa data primer hasil wawancara dan didukung data sekunder dari data serta dokumen. Adapun proses pengumpulan data melalui wawancara, observasi, dan analisis dokumen. Data lalu dianalisis dengan teknik analisis data berupa model analisis interaktif. Milles \& Huberman (Sutopo, 2002), menyatakan bahwa analisis interaktif dapat dilakukan dengan memperhatikan 3 (tiga) komponen utama, yang meliputi reduksi data, sajian data serta penarikan kesimpulan dan verifikasinya.

III. Indikator

Pemberdayaan Masyarakat

Pengertian pemberdayaan dapat dipahami dalam berbagai definisi. Mardikanto menjelaskan definisi pemberdayaan adalah upaya untuk meningkatkan masyarakat dari yang miskin, marginal, terpinggirkan sehingga mampu memenuhi kebutuhannya dan atau menyampaikan pendapatnya, pilihan - pilihannya, berpartisipasi, bernegosiasi, mempengaruhi dan mengelola kelembagaan masyarakat secara bertanggung jawab (accountable) dalam rangka perbaikan kehidupannnya (Mardikanto 2010:41).

Sementara seorang ahli pemberdayaan masyarakat, Robert Chambers (Alfitri, 2011), mendefinisikan pemberdayaan masyarakat sebagai konsep dalam pembangunan ekonomi yang di dalamnya merangkum nilai-nilai sosial. Di dalam konsep ini, terdapat paradigma baru pembangunan, yaitu bersifat people centered, participatory, empowering, dan sustainable. Sedangkan Swift dan Levin (Mardikanto, 2010), menguraikan definisinya mengenai usaha 
pemberdayaan masyarakat yang merujuk pada kemampuan kelompok rentan dan lemah, agar dapat :

1. Memiliki akses terhadap sumber-sumber produktif, yang memungkinkannya untuk dapat meningkatkan pendapatan dan memperoleh barang-barang dan jasa-jasa yang diperlukan.

2. Berpartisipasi dalam proses pembangunan serta keputusan-keputusan yang mempengaruhi mereka, serta menunjuk pada usaha pengalokasian kembali kekuasaan melalui perubahan struktur sosial.

Undang - Undang Nomor

9 Tahun 1995 sendiri lebih menekankan pengertian pemberdayaan sebagai upaya yang dilakukan pemerintah, dunia usaha, dan masyarakat dengan jalan penembuhan iklim usaha, pembinanaan dan pengembangan agar industri kecil mampu menumbuhkan dan memperkuat dirinya menjadi usaha tangguh dan mandiri. Adapun pembinaan dan pengembangan yang dimaksud adalah suatu upaya yang dilakukan pemerintah, dunia usaha dan masyarakat dengan jalan pembimbingan dan pembantuan dalam rangka penguatan sehingga mampu menumbuhkan dan meningkatkan kemampuan industri kecil.

Dari berbagai definisi konsep pemberdayaan masyarakat yang telah disampaikan di atas, dapat disimpulkan pengertian inti pemberdayaan masyarakat adalah upaya peningkatan kemampuan orang, khususnya kelompok yang rentan dan lemah (tidak berdaya) untuk meningkatkan kapasitas SDM dalam rangka meningkatkan kapasitasnya, melalui usaha peningkatan kompetensi dan pengetahuan yang bermanfaat untuk meningkatkan keberdayaannya serta mencapai tujuannya.

Peningkatan kapasitas SDM ini perlu diperkuat dengan pengembangan kelembagaan yang terkait dengan keorganisasian lokal. Penguatan masyarakat sendiri dapat diartikan dalam makna ganda yang bersifat timbal balik. Di satu sisi, penguatan masyarakat diarahkan agar lebih memampukan individu sehingga dapat mampu berperan dalam kelompok dan masyarakat global, di tengah - tengah ancaman yang dihadapi dari berbagai pihak, seperti dalam kehidupan pribadi, kelompok dan masyarakat global. 
Di sisi lain, penguatan masyarakat juga diarahkan agar masyarakat mampu melihat peluang yang berkembang di lingkungan kelompok dan masyarakat global sehingga dapat dimanfaatkan bagi perbaikan kehidupan pribadi, kelompok dan masyarakat global (UNDP, 1998).

Pemberdayaan

masyarakat juga dapat dipengaruhi oleh beberapa indikator. Adapun indikator utama pemberdayaan masyarakat menurut Sumadyo (Mardikanto dan Subianto, 2012) dipengaruhi oleh Bina Manusia, Bina Usaha, dan Bina Lingkungan, ditambah dengan indikator pelengkap berupa Bina Kelembagaan. Berikut adalah penjelasan masingmasing indikator pemberdayaan masyarakat tersebut :

1. Bina Manusia, mengkaji pengembangan kapasitas individu, pengembangan kapasitas entitas/ kelembagaan, dan pengembangan kapasitas sistem/ jejaring.

2. Bina Usaha, mengkaji halhal meliputi: (1) pemilihan komoditas dan jenis usaha, (2) studi kelayakan dan perencanaan bisnis, (3) pembentukan badan usaha,
(4) perencanaan investasi dan penetapan sumber-sumber pembiayaan, (5) pengelolaan SDM dan pengembangan kariri, (6) manajemen produksi dan operasi, (7) manajemen logistik dan financial, (8) penelitian dan pengembangan, pengembangan dan pengelolaan system informasi bisnis, (10) pengembangan jejaring dan kemitraan, (11) pengembangan sarana dan prasarana pendukung.

3. Bina Lingkungan, mengkaji lingkungan fisik secara luas, yang tidak sekedar berbicara tentang pertanggung jawaban lingkungan sosial yang terkait upaya perbaikan kesejahteraan sosial masyarakat yang tinggal di sekitar areal kerja. Lebih dari itu, proses pemberdayaan masyarakat dalam pelaksanaannya perlu memperhatikan lingkungan fisik terutama yang menyangkut pelestarian sumber daya alam dan lingkungan hidup.

\section{Bina Kelembagaan,} mengkaji tentang penyelenggaraan kelembagaan sosial atau 
organisasi sosial yang tersedia agar dapat berjalan efektif utuk mendukung terselenggaranya Bina Manusia, Bina Usaha, dan Bina Lingkungan. Relasi sosial baru dapat disebut sebagai sebuah kelembagaan apabila memenuhi 4 (Empat) kompone, berupa:

Komponen Personal,

Komponen Kepentingan, (3)

Komponen Aturan,

Komponen Struktur.

Keempat indikator ini dapat menjadi dasar guna mengkaji permasalahan yang dirumuskan dalam penelitian dengan tema pemberdayaan masyarakat pengrajin gitar yang berbentuk UMKM di Kabupaten Sukoharjo ini. Penelitian ini menggunakan indikator bina manusia, bina usaha, bina lingkungan serta bina kelembagaan yang dilakukan pemerintah dalam suaha peningkatan kompetensi UMKM.

\section{Implementasi Pemberdayaan}

\section{Pengrajin Gitar}

Upaya pemberdayaan masyarakat bermuara pada tujuan kesejahteraan masyarakat. Hal ini pula yang berlaku bagi para pengrajin gitar Desa Mancasan, Kecamatan Baki, Kabupaten

Sukoharjo. Melalui industri kecil gitar di Desa Mancasan Kecamatan Baki, masyarakat dapat terperdayakan hingga hampir seluruh warga Desa ini mengandalkan kerajinan gitar sebagai sumber pendapatan demi mencapai kesejahteraan. Hasil ini dapat dicapai dengan dukungan program pemberdayaan masyarakat melalui pembinaan industri sebagai wujud dari manifestasi dari paradigma Good Governance.

Adapun pencapaian ini dapat terwujud dengan adanya sinergitas masyarakat, pemerintah, dan juga sektor swasta. Dengan kata lain, upaya pemberdayaan masyarakat perlu melibatkan masyarakat dengan segala potensi yang dimilikinya. Hubungan ini membutuhkan paradigma good governance yang menempatkan pemerintah daerah untuk dapat berperan dominan untuk memetakan serta mengarahkan kondisi, potensi, dan kebutuhan masyarakatnya.

Penelitian r ini
menemukan bahwa andil
pemerintah dalam
pemberdayaan pengrajin gitar di
Desa Mancasan telah diwujudkan
dengan dasar Undang-Undang
Nomor 20 tahun 2008 tentang


Usaha Mikro, Kecil, dan Menengah yang mewadahi prinsip penyelenggaraan program

UMKM, berupa :

a. Penumbuhan kemandirian, kebersamaan, dan kewirausahaan Usaha Mikro, Kecil, dan Menengah untuk berkarya dengan prakarsa sendiri;

b. Perwujudan kebijakan publik yang transparan, akuntabel, dan berkeadilan;

c. Pengembangan usaha berbasis potensi daerah dan berorientasi pasar sesuai dengan kompetensi Usaha 3 / 24 Mikro, Kecil, dan Menengah;

d. Peningkatan daya saing Usaha Mikro, Kecil, dan Menengah; dan

e. Penyelenggaraan

perencanaan, pelaksanaan, dan pengendalian terpadu.

Dengan landasan hukum yang jelas, pemerintah dapat menata langkah strategis untuk program pemberdayaan UMKM di bawah binaannya. Adapun tujuan program UMKM yang ditargetkan pemerintah, meliputi :

a. Mewujudkan struktur perekonomian nasional yang seimbang, berkembang, serta berkeadilan;

b. Menumbuhkan dan mengembangkan kemampuan UMKM untuk menjadi usaha yang tangguh dan mandiri;

c. Meningkatkan peran UMKM dalam usaha pembangunan daerah, penciptaan lapangan kerja, pemerataan pendapatan, pertumbuhan ekonomi, dan juga pengentasan rakyat dari kemiskinan.

Secara lebih rinci, usaha pemberdayaan masyarakat pengrajin gitar ini dipetakan dalam empat aspek, yakni bina manusia, bina usaha, bina lingkungan serta bina kelembagaan. Bina manusia menjadi langkah pertama dan utama yang penting dalam setiap upaya pemberdayaan masyarakat. Adapun upaya bina manusia meliputi seluruh kegiatan penguatan atau pengembangan kapasitas individu, entitas/ kelembagaan, dan sistem/ jejaring.

\section{Bina Manusia}

Penelitian yang dilakukan menemukan bahwa para pengrajin gitar Desa Mancasan menyadari bahwa pengembangan kapasitas SDM adalah kewajiban mereka masing-masing dan penting dilakukan mengingat 
tantangan global yang semakin meningkat. Persaingan mengharuskan mereka untuk bisa berkembang. Meski demikian, pengembangan kapasitas ini masih belum diupayakan secara maksimal oleh para pengrajin secara pribadi. Proses pengembangan kapasitas yang selama ini dilakukan lebih bergantung pada kegiatan paguyuban.

$$
\text { Adapun peran }
$$

pemerintah dalam bina manusia ini dilakukan melalui keterlibatan dinas perdagangan, koperasi Industri kecil dan menengah. Salah satu peran pentingnya adalah membentuk paguyuban para pengrajib gitar. Lalu, melalui paguyuban ini, pemerintah secara rutin memfasilitasi kegiatan pelatihan, bimtek, studi banding serta pertemuan rutin untuk mendukung perkembangan kapasitas sebagai bentuk bina manusia.

\section{Bina Usaha}

Pada aspek bina usaha, orientasinya adalah perbaikan ekonomi dan kesejahteraan masyarakat. Para pengrajin gitar Desa Mancasan sendiri mayoritas menyadari bahwa bina usaha adalah hal penting guna menunjang keberlanjutan industrinya. Namun demikian, keterbatasan pemahaman membuat aspek ini tidak dilakukan secara merata. Sebagian pengrajin telah mampu melakukan bina usaha atas inisiasi sendiri, sementara sebagian lainnya tidak melakukan pengembangan usaha secara pribadi, kecuali hanya mengandalkan keterlibatan pemerintah dan paguyuban.

Pada dasarnya, ada banyak kegiatan yang mendukung kegiatan bina usaha, meliputi : (1) pemilihan komoditas dan jenis usaha, (2) studi kelayakan dan perencanaan bisnis, pembentukan badan usaha, (4) perencanaan investasi dan penetapan sumber pembiayaan, (5) pengelolaan SDM dan pengembangan karir, manajemen produksi dan operasi, (7) manajemen logistik dan finansial, (8) penelitian dan pengembangan, pengembangan dan pengelolaan system informasi bisnis, (10) pengembangan jejaring dan kemitraan, (11) pengembangan sarana dan prasarana pendukung. Peran pemerintah yang dianggap telah dikelola dengan baik adalah dukungan dalam pembentukan badan usaha. Hal ini dilakukan dengan pengadaan 
sosialisai dan pendampingan untuk mengurus badan usaha. Efektivitas langkah ini dapat dilihat dari para pengrajin gitar Desa Mancasan yang mayoritas telah memiliki badan usaha, hanya beberapa saja yang masih belum memiliki. Selain itu, studi kelayakan dan aspek perencanaan bisnis juga cukup baik dilakukan. Hal ini dilakukan melalui koordinasi dengan paguyuban, dan telah banyak menghasilkan program. Meski demikian, realisasi program hasil studi kelayakan ini dianggap belum maksimal karena pelaksanaannya yang kadang tidak sesuai dengan perencanaan program.

\section{Bina Lingkungan}

Bina lingkungan menjadi aspek penting dalam melengkapi pemberdayaan masyarakat yang bertanggung jawab. Pertanggungjawaban ini tidak hanya dilihat dari lingkungan sosial dalam rangka mensejahterakan masyarakat saja, melainkan juga dengan memperhatikan lingkungan fisik terkait pelesterian lingkungan hidup dan sumber daya alam. Pentingnya bina lingkungan ini juga telah disadari oleh para pengrajib gitar Desa Mancasan. Hanya saja, selama ini upaya yang mengarah pada bina lingkungan tidak ada. Ini lantaran persepsi masyarakat yang beranggapan bahwa industri gitar tidak berdampak negatif terhadap lingkungan.

Limbah kayu dan debu hasil pengelolaan industri gitar dianggap bukan sesuatu yang merusak. Apalagi, tidak ada protes masyarakat terkait dampak negatif lingkungan dari kegiatan kerajinan gitar. Padahal, bila dirunut lebih jauh lagi, ada potensi ketidakseimbangan lingkungan dari kegiatan industri gitar, seperti debu serta penggunaan kayu yang berlebihan sebagai bahan dasar gitar. Idealnya, dibutuhkan pelestarian kayu serta standarisasi yang mendukung bina lingkungan. Dalam hal ini, pemerintah telah berperan dalam mewacanakan untuk bina lingkungan. Hanya saja, tindak lanjut dari wacana tersebut yang masih belum terealisasi sehingga tidak ada tindakan bina lingkungan yang dilakukan di kalangan pengrajin gitar Desa Mancasan.

\section{Bina Kelembagaan}

Aspek bina kelembagaan ini berkaitan dengan pengelolaan serta ketersediaan kelembagaan sosial atau organisasi sosial. Sasaran bina 
kelembagaan adalah adanya organisasi atau lembaga yang mampu berjalan secara efektif untuk mendukung terselenggaranya Bina Manusia, Bina Usaha, maupun Bina Lingkungan. Kelembagaan merujuk pada wadah bagi relasi sosial, yang di dalamnya harus memenuhi 4 (empat) komponen, berupa :(1) Komponen Personal, (2) Komponen Kepentingan, (3) Komponen Aturan, (4) Komponen Struktur.

Bina kelembagaan ini berkenaan dengan perilaku, atau seperangkat mores ataupun cara bertindak yang mantap yang berjalan di masyarakat. Dalam usaha untuk mendukung penyelengaraan kelembagaan sosial atau organisasi sosial di sentra industri gitar Desa Mancasan Kabupaten Sukoharjo, peran pemerintah terletak pada interaksinya dengan paguyuban. Pemerintah melakukan pertemuan dengan paguyuban untuk membangun kekuatan kelembagaan yang lebih ideal. Hanya saja, keterlibatan pemerintah dalam paguyuban ini dianggap masih belum maksimal karena intensitas pertemuan dan pelatihan yang minim.

\section{Pengrajin Gitar Mancasan Menuju Pasar Global}

Upaya penguatan

kapasitas masyarakat yang dilakukan terhadap para pengrajin gitar di Desa Mancasan membutuhkan sinergi dan konsolidasi yang menyeluruh. Keberhasilan dari proses pemberdayaan masyarakat ini tidak hanya terletak pada peran pengelola atau fasilitator program semata, melainkan juga perlu didukung peran serta masyarakat. Selain itu, indikator keberhasilan pemberdayaan yang dilakukan juga tidak bisa hanya diakui oleh pemerintah sebagai fasilitator saja, melainkan juga harus diakui oleh masyarakat (Mardikanto: 2003).

Para pengrajin gitar memiliki modal kekuatan dan daya saing yang secara aktif perlu untuk dikembangkan secara terus menerus. Pemberdayaan ini harus terus dikuatkan agar mampu menghasilkan atau "memproduksi" sesuatu yang lebih bermanfaat dan lebih unggul. Pemberdayaan masyarakat diarahkan untuk melebihmampukan individu untuk berperan di dalam kelompoknya sekaligus dalam persaingan di masyarakat global. Sejak, masyarakat global yang dinamis 
dan terus berkembang juga harus dihadapi dengan bekal yang cukup dan matang.

Untuk itu, salah satu usaha penguatan masyarakat para pengrajin gitar di Desa Mancasan juga diarahkan untuk melihat peluang yang berkembang di lingkungan masyarakat global. Dalam hal ini, kegiatan yang dilakukan adalah strategi ekspor untuk ekspansi usaha agar masyarakat lebih berdaya saing. Pasar internasional yang luas menjadi kesempatan untuk para pengrajin gitar Desa Mancasan untuk berkembang. Kemampuan untuk menangkap peluang ekspor ini menunjukkan adanya peningkatan daya saing sebagai hasil pemberdayaan masyarakat yang lebih besar.

Penelitian ini
menunjukkan bahwa para
pengrajin gitar Desa Mancasan
menyadari bahwa perluasan pasar
domestik menuju pasar ekspor
adalah hal penting. Mereka juga
menyadari potensi besar yang
tersedia di lahan ekspor. Bahkan
pasar internasional dianggap lebih
potensial dibanding pasar
domestik.

Pemerintah juga telah berperan dalam mendorong para pengrajin gitar Desa Mancasan untuk melakukan ekspor. Hal ini dilakukan melalui motivasi. Para pengrajin juga telah melakukan studi banding ke para pengusaha ekspor gitar dan mempelajari strategi ekspor. Hanya saja, ketiadaan fasilitasi untuk ekspor dari pemerintah menjadi masalah tersendiri. Minimnya jaringan dan kemampuan ekspansi dari para pengrajin pun mengjadi hambatan utama untuk bisa menembus pasar ekspor. Karenanya, strategi ekspor yang dilakukan masih belum bisa dikatakan berhasil.

\section{Daftar Pustaka}

Alfitri. 2011. Community Development: Teori dan Aplikasi. Yogyakarta: Pustaka Pelajar.

Alsop, Ruth; Mette Frost Bertelsen; dan Jeremy Holland. 2006. Empowerment in Practice From Analysis to Implementation. Washington, DC: The World Bank.

Azizy, Ahmad Qodri A. 2003. Pemberdayaan Masyarakat dalam Pengembangan Kehidupan Berdemokrasi di Indonesia. Jakarta: Lembaga Executive Club (LEC) Press.

Daroin, Ana Dhaoud. 2015. "Upaya Pengembangan Usaha Mikro Kecil dan Menengah (UMKM) Handycraft Kayu Jati di Dusun Bandar Desa Batokan Kecamatan Kasiman Kabupaten Bojonegoro". Thesis Program Pascasarjana Magister Pendidikan Ekonomi 
Universitas Sebelas Maret. Tidak diterbitkan.

Hidayat, Wahid Anggih. 2013. "Pembinaan UMKM Kota Surakarta oleh Dinas Koperasi dan UMKM Kota Surakarta". Skripsi S1 Ilmu Administrasi Negara Fakultas Ilmu Sosial dan Ilmu Politik Universitas Sebelas Maret. Tidak diterbitkan.

Mardalis. 2002. Metode PenelitianSuatu Pendekatan Proposal. Jakarta: Bumi Aksara.

Mardikanto, Totok dan Poerwoko Soebianto. 2015.

Pemberdayaan Masyarakat dalam Perspektif Kebijakan Publik. Bandung : Alfabeta. 2010. Konsep-Konsep Pemberdayaan Masyarakat. Surakarta: Fakultas Pertanian UNS dengan UPT Penerbitan dan Percetakan UNS (UNS Press).

2010. Model-Model Pemberdayaan Masyarakat. Surakarta: UPT Penerbitan dan Percetakan UNS (UNS Press).

Narayan, Deepa. (ed). 2002. Empowerment And Poverty Reduction: A Source book. Washington, DC: PREM The World Bank.

Purlys, Cheslovas. 2007. Export Marketing and Promotion : Analysis of Theory and Practices for Composing of Lithuanian Export Promoting Strategy. Vilniaus Gediminas Technical University : Economika ir Vadyba ISSN 1648 -9098.

Quinlan, Reginald. 1990. An Evaluation of the Theory of Export Market Entry Strategies with Specific Reference to the Irish Food and Drink Industry. Dublin : Dublin City University

Santosa, Pandji. 2008. Administrasi Publik Teori dan Aplikasi Good Governance. Bandung : PT. REFIKA ADITAMA

Sayaefuddin, Fahmi. 2013. "Implementasi Program One Village One Product (OVOP) Dalam Rangka Pemberdayaan Usaha Mikro Kecil dan Mennegah (UMKM) (Studi Kasus di Kampung Wisata Batik Kauman Kota Surakarta).” Skripsi Jurusan Ilmu Administrasi Fakultas Ilmu Sosial dan Ilmu Politik Universitas Sebelas Maret. Tidak diterbitkan.

Sedarmayanti. 2003.

Good

Governance. Bandung : Mandar Maju.

Sevilla, Consuelo G, Jesus A. Ochave, Twila G. Punsalan, Bella P. Regala, dan Gabriel G. Uriarte. 1993. Pengantar Metode Penelitian (Edisi terjemahan Alimuddin Tuwu). Jakarta: Penerbit Universitas Indonesia (UI-Press).

Slamet, Y. 2006. Metode Penelitian Sosial. Surakarta: Sebelas Maret University Press.

Subejo dan Supriyanto. 2005. Kerangka Pemberdayaan Masyarakat Pedesaan Menuju Pembangunan yang Berkelanjutan. Jurnal IlmuIlmu Pertanian. No.1 Juli (2005). 17-32.

Sugiyono. 2009. Metode Penelitian Kuantitatif Kualitatif dan $R$ \& D. Bandung: Penerbit ALFABETA.

Sumodiningrat, Gunawan. 2007. Pemberdayaan Sosial: Kajian Ringkas tentang Pembangunan Manusia 
Indonesia. Jakarta: Penerbit Buku Kompas.

Sutopo, H.B. 2002. Metode Penelitian Kualitatif - Dasar teori dan terapannya dalam penelitian. Surakarta: Sebelas Maret University Press.

Wrihatnolo, Randy R dan Riant Nugroho Dwidjowojoto. 2007.
Manajemen Pemberdayaan: Sebuah Pengantar dan Panduan Untuk Pemberdayaan Masyarakat. Jakarta: PT Elex Media Komputindo. 